Technical note

Volumen 32(1):306-315. Enero-abril, 2021

e-ISSN 2215-3608, doi:10.15517/am.v32i1.40965

http://www.revistas.ucr.ac.cr/index.php/agromeso

\title{
Erwinia billingiae causes bacterial Canker of Mango (Mangifera indica) in Costa Rica ${ }^{1}$
}

\section{Erwinia billingiae agente causal del cáncer bacteriano del mango (Mangifera indica) en Costa Rica}

\author{
Daniela Vidaurre-Barahona ${ }^{2}$,Amy Wang-Wong ${ }^{3}$, Lorena Uribe-Lorío $0^{2,4}$
}

1 Reception: 4 de marzo, 2020. Acceptance: 7 de julio, 2020. This work was part of the project number VI-801-A5-520 registered in Vicerrectoría de Investigación of the Universidad de Costa Rica.

2 Universidad de Costa Rica, Environmental Microbiology Department, Cellular and Molecular Biology Research Center, 11501-2060, San Pedro de Montes de Oca, San Jose, Costa Rica. lorena.uribe@ucr.ac.cr (https://orcid.org/000-0002-6023-0997), daniela.vidaurre@ucr.ac.cr (correspondence autor, https://orcid.org/0000-0002-9221-0560).

3 Universidad de Costa Rica, Plant Pahology Laboratory, Crop Protection Research Center, 11501-2060, San Pedro de Montes de Oca, San Jose, Costa Rica. amy.wang@ucr.ac.cr (https://orcid.org/0000-0002-6149-3035)

4 Universidad de Costa Rica, School of Agronomy, 11501-2060, San Pedro de Montes de Oca, San Jose, Costa Rica.

\begin{abstract}
Introduction. In Costa Rica, bacterial canker of mango has caused economic losses in most of the productive areas since the mid-1980s. The causal agents have been identified only by phenotypic methods such as Erwinia mangifera and E. herbicola. Objective. To confirm, using a molecular and phenotypic approach, the species of the Enterobacteriaceae the cause bacterial canker of mango in Costa Rica. Material and methods. Fruits, branches, and trunks with symptoms were collected in different orchards in the Alajuela province. Bacterial isolation was performed, and pathogenicity was evaluated by inoculating fruits and trunks of the Tommy Atkins variety. The positive isolates for the pathogenic test were re-inoculated, isolated, and identified in order to fulfill Koch's postulates. The CIBCM$\mathrm{Mg}-115$ positive isolate that caused symptoms was analyzed by complete biochemical characterization and molecular identification by phylogenetic analyses of $16 \mathrm{~S}$ rRNA and the atpD, gyrB, infB, and rpoB housekeeping genes. Results. According to the data obtained from the biochemical and molecular analysis, the CIBCM-Mg-115 strain was identified as Erwinia billingiae. Conclusion. E. billingiae corresponds to one of the causal agents of bacterial canker on mango (M. indica) trees in Costa Rica.
\end{abstract}

Keywords: Enterobacteriaceae, Tommy Atkins, Erwinia mangifera, Erwinia herbicola.

\section{Resumen}

Introducción. El cáncer del mango ha ocasionado pérdidas económicas en áreas productivas en Costa Rica desde mediados de los 80. Los agentes causales han sido caracterizados solamente por métodos fenotípicos como Erwinia mangifera y E. herbicola. Objetivo. Confirmar, utilizando un enfoque molecular y fenotípico las especies de enterobacterias causantes del cáncer bacterial del mango en Costa Rica. Materiales y métodos. Se tomaron frutas, ramas y troncos con síntomas en diferentes huertos de la provincia de Alajuela. Se realizó un aislamiento 
bacteriano y se evaluó la patogenicidad mediante la inoculación de frutos y troncos de la variedad Tommy Atkins Los aislamientos positivos para la prueba de patogenicidad fueron re-inoculados, aislados e identificados para cumplir con los postulados de Koch. El aislado positivo CIBCM-Mg-115 que causó los síntomas fue analizado mediante la caracterización bioquímica completa y la identificación molecular mediante análisis filogenéticos del ARNr $16 \mathrm{~S}$ y los genes de mantenimiento atpD, gyrB, infB y rpoB. Resultados. De acuerdo con los datos obtenidos a partir de los análisis bioquímicos y moleculares se identificó a la cepa CIBCM-Mg-115 como Erwinia billingiae. Conclusión. E. billingiae corresponde a uno de los agentes causales del cáncer bacteriano del mango (M. indica) en Costa Rica.

Palabras clave: Enterobacteriaceae, Tommy Atkins, Erwinia mangifera, Erwinia herbicola.

\section{Introduction}

Mangifera indica crops established in tropical regions are susceptible to different diseases caused by microorganisms. Mango anthracnose is the most important causing losses in the field and as well as in postharvest (Arauz, 2000). Within the common bacterial diseases, Xanthomonas campestris pv. mangiferaeindicae and Pseudomonas syringae pv. syringae has been reported as causal agents of canker of mango and bacterial apical necrosis of mango respectively (Pruvost et al., 2012; Yanxiang et al., 2016; Young, 2008).

Bacterial Canker of Mango (M. indica) was first described in South Africa in 1915 by Doidge (Steyn et al., 1974). In India, the disease emerged in 1948 (Kishun, 1982), while in America, it was found for the first time in Rio de Janeiro, Brazil in 1955 (Robbs \& Rezende, 1978). In Venezuela its presence was reported in 1970 (Rondón \& Figueroa, 1970) and named fruit spot. In Costa Rica, it was first observed in 1987 (Sáenz \& Murillo, 1989) and after that, it has caused premature fruit drop (10-70 \%) loss of production (10-85\%) and rot in storage (5-100 \%) (Ureña et al., 2007). It was considered systemic due to its wide distribution in the plant, causing symptoms in all parts of the trees, and a pre-harvest disease affecting fruits, branches, inflorescences and peduncles (Viljoen \& Kotzë, 1972; Guevara et al., 1980). The main symptom in the trunk and branches is a resinous light colored (almost beige) exudate that becomes dark brown with time. Fruits are affected by an internal rot which is difficult to detect in the initial stages and later develops into a black spot on the fruit surface (Mora et al., 2002).

Bacteriosis caused by Erwinia genus is characterized by reddish brown spots or striations on the phloem of infested tree branches and trunks where lesions or cankers with rubbery exudate are observed. In the fruits the lesion is observed externally as an irregular and sunken black spot in the peduncular region, although it can also appear in other sectors of the fruit and internally necrosis is observed around the seed. In the leaves, the bacteria are found associated with fungi of the genus Colletotrichum sp. causing small, angular spots of 2 to $3 \mathrm{~mm}$, sometimes large spots on the edges that give it a burnt appearance (Ureña et al., 2007).

The bacteria are perpetuated in epiphytic form in various plant organs, when the environmental conditions are unfavorable to the development of the disease or the tree is in a vegetative period. Bacteria are spread by rain, cuttings, and insects (Ureña et al., 2007). The disease is more prevalent in locations with precipitation greater than $850 \mathrm{~mm}$ per year, relative humidity above $80 \%$ and temperatures between 24 and $32{ }^{\circ} \mathrm{C}$. These conditions are ideal for pathogen dissemination and infection (Guevara et al., 1985), especially in the Tommy Atkins variety (Mora et al., 2002).

In Costa Rica, mango production has been decreasing due to different factors (López, 2011), one of which is bacterial canker caused by an enterobacteria (McMillan \& Wang, 1992) and not by Xanthomonas citri pv. Mangiferae indicae; were Erwinia was isolated from disease trees of Tommy Atkins variety and characterized by phenotypic traits. The causal agent has been identified by several authors previously using conventional phenotypic methods as Erwinia mangifera, Erwinia herbicola, and Pectobacterium sp. (Guevara et al., 1985; Rondón \& 
Figueroa, 1970; Steyn et al., 1974), but there have not been further reports of molecular or polyphasic identification of this bacteria.

The aim of this study was to confirm, using a molecular and phenotypic approaches the species of the enterobacteria causing bacterial canker in mango in Costa Rica.

\section{Material and methods}

Fruits, branches, and trunks with symptoms previously described as reddish striations and rubbery exudates on the trunk while the fruits showed a black spot in the peduncular region and fruit internally necrosis near to the seed (Figure 1), were collected in different orchards from Alajuela province, Costa Rica, during the second semester of 2008.

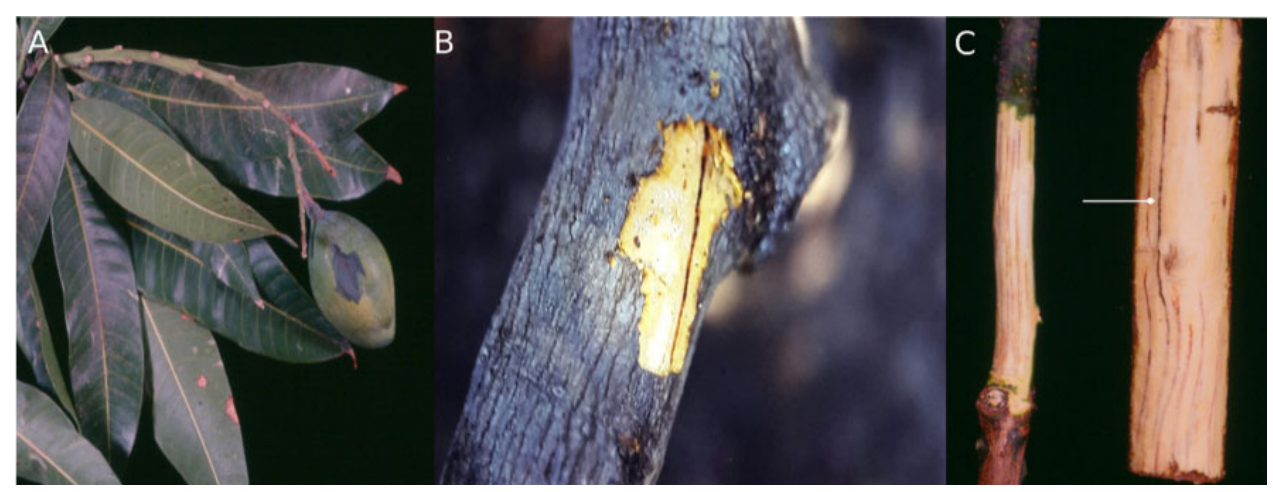

Figure 1. Mango plant tissue (M. indica) showing bacterial symptoms. Alajuela, Costa Rica. 2008.

A. Young plant with typical symptoms caused by the Erwinia-like bacterium. Note the black and irregular shape of the lesion. B, C. Striation in the outer cortex.

Figura 1. Tejido de plantas de mango (M. indica) con síntomas bacterianos. Alajuela, Costa Rica. 2008.

A. Planta joven con síntomas causados por una bacteria del género Erwinia. Se observa una lesión de coloración negruzca y con forma irregular. B, C. Estriación en la corteza exterior.

Bacterial isolation was performed for the three types of tissues. Sterilization procedure was carried out to 7 $\mathrm{cm}$ sections from two branches, one trunk and two complete fruits using $1 \%$ sodium hypochlorite for 1 minute followed by sterile distilled water rinse twice.

A piece of each diseased tissue was removed using a sterilized scalpel and placed in nutrient agar (NA Oxoid, Basingstoke, UK). Plates were incubated for $48 \mathrm{~h}$ at $30{ }^{\circ} \mathrm{C}$ or until growth was observed. Colonies that showed morphological differences by Gram stain were purified using an enterobacteriaceae selective medium (MacConkey agar, Oxoid, Basingstoke, UK) and the streak plate method to separate bacterial cells on the agar surface to obtain isolated colonies. Purified strains were further differentiated using preliminary phenotypic tests (Schaad et al., 2001), and biochemical features as fermentations of dextrose, lactose and saccharose by TSI (Triple Sugar Iron Agar) and oxidase tests.

Pathogenicity of the bacterial isolates was assessed inoculating by injection two physiological ripeness fruits and two trunks of the Tommy Atkins variety with $0.5 \mathrm{ml}$ of a calibrated $1 \times 10^{7} \mathrm{CFU} \mathrm{ml}{ }^{-1}$ suspension of each isolate. Sterile distilled water was used as negative control. Inoculation was done using a sterile needle. When inoculating trunks of young trees, a small injury was performed to facilitate the entrance of the pathogen. Inoculated material 
were incubated under greenhouse conditions at $25-30{ }^{\circ} \mathrm{C}$. After infection, the young trees were covered for 24 hours with a plastic bag, large enough to simulate a moist chamber. After this period, the bags were removed, and the trees were kept in the greenhouse for infection to occur until first symptoms were evident. Only positive isolates that caused symptoms, were analyzed by molecular identification and complete biochemical characterization and were re-isolated from inoculated into fruit and identified, thereby, fulfilling Koch's postulates (Figure 2).
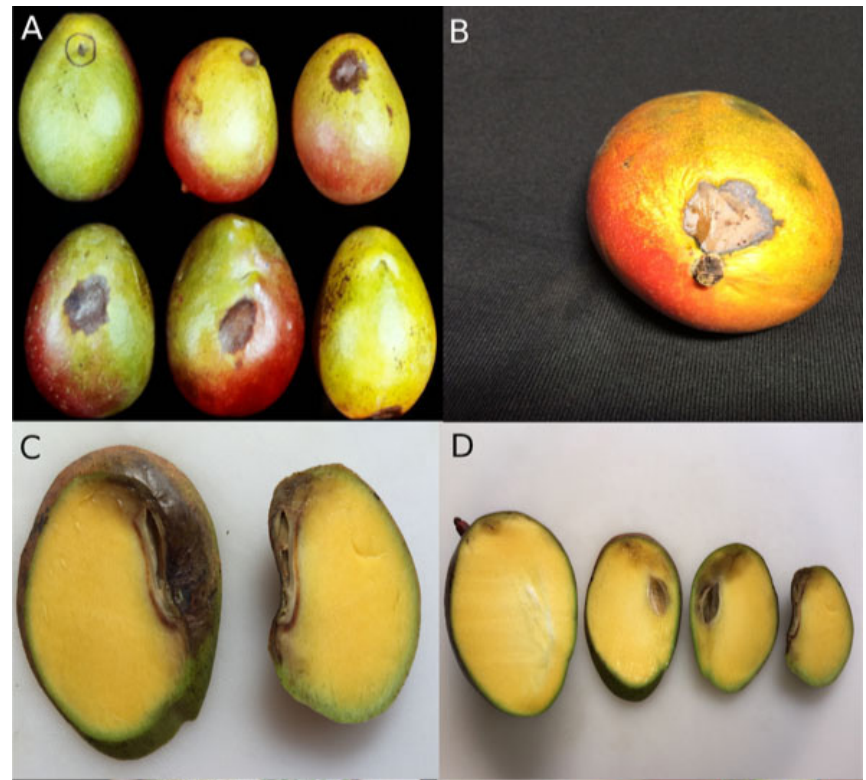

D

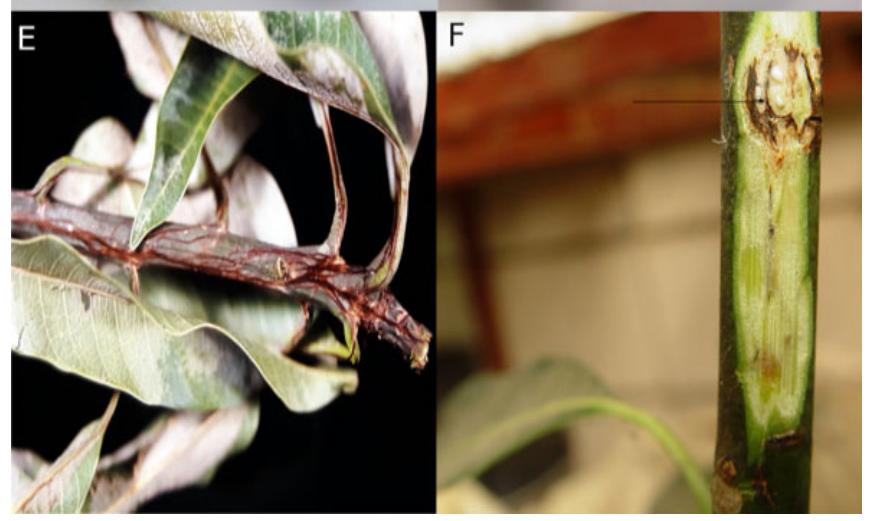

Figure 2. Symptoms of infection observed in situ and by inoculation of the CIBCM-Mg-115 strain, in mango fruits and tissue ( $M$. indica). San José, Costa Rica. 2008.

A, C. Natural infection where a dark lesion with slight sinking is observed at the foot of the fruit. B, D. Symptoms observed by the artificial inoculation of $0.5 \mathrm{ml}$ of a $1 \times 107 \mathrm{cfu} \mathrm{ml}^{-1}$ bacterial suspension. E. Advancement of the lesion when the infection occurs in the inflorescence or in an outbreak. F. Milky sap flowing through fissures, also described in branches and panicules.

Figura 2. Síntomas de infección observados in situ y mediante inoculación de la cepa CIBCM-Mg-115, en frutos y tejido de mango (M. indica). San José, Costa Rica. 2008.

A. C. Infección natural donde se observa una lesión oscura y con hundimiento leve en el pie del fruto. B, D. Síntomas observados por la inoculación artificial de $0,5 \mathrm{ml}$ de una suspensión bacteriana de 1 x 107 cfu ml-1. E. Avance de la lesión cuando la infección ocurre en la inflorescencia o el brote. F: Savia lechosa fluyendo a través de las fisuras según lo observado en ramas y panículas. 
Genomic DNA was extracted using the DNeasy Blood \& Tissue Kit (Qiagen $\left.{ }^{\circledR}\right)$ following the manufacturer's instructions. PCR was used to amplify $16 \mathrm{~S}$ rRNA and recA, gyr B, dna,$g l t \mathrm{X}$, and $r p o \mathrm{~B}$ housekeeping genes (Tailliez et al., 2010). Sequences of all genes were obtained from Macrogen Inc. Contig assembly and ambiguity resolution were performed with BioEdit (Hall, 1999). Sequences were aligned with reference sequences from the NCBI database in MEGA (Tamura et al., 2013). Multiple sequence alignments were performed with ClustalX (Larkin et al., 2007). Sequences corresponding to PCR amplification primers were removed prior to multiple sequence alignment and phylogenetic analysis. All of the sequenced genes were analyzed separately and then in a concatenated tree. Evolutionary distances were calculated by Bayesian inference and tree topology was evaluated by bootstrap analysis with 10000000 resampling.

Phenotypic characterization was based on biochemical tests using the semi-automated identification systems API 20E, API 50CHE (bioMérieux) and GN microplates (BIOLOG), conducted as recommended by the manufacturers. Tests known to differentiate between Erwinia species and Pantoea were used to compare the mango isolate (CIBCM-Mg-115) with type strains from species of the genus Erwinia by clustering analysis using the statistical program PAST (Hammer et al., 2001).

\section{Results}

Five bacterial isolates were obtained and tested. Only CIBCM-Mg-115 strain isolated from fruit caused symptoms when inoculated on fruits and trunks of young trees. The symptoms were brownish to black lesion appeared near to the shoulder of the fruit that continued to the internal part of the fruits as well as milky sap in trunk lesions. Lesions were observed after 30 and seven days post infections for trunks and fruits, respectively. Koch's postulates were accomplished by re-isolating and identifying from fruits the same pathogen obtained from the same tissue showing symptoms originally.

The Bayesian phylogenetic tree based on 16S rRNA gene sequences (Figure 3) from members of the genera Erwinia and Pantoea indicated that strain CIBCM-Mg-115 was most closely related to Erwinia billingiae (DSM 23398T).

The phylogenetic tree based on concatenated housekeeping gene sequences (Figure 4) demonstrated that the Costa Rican strain showed high homology to strains of E. billingiae and formed a cluster supported by a high bootstrap value. This is consistent with the results of the phylogenetic analysis based on 16S RNA and suggest that the isolate is related to Erwinia species pathogenic to papaya (Carica papaya): E. papayae; cantaloupe (Cucumis melo): E. tracheiphyla; guava (Psidium guajava): E. psidii; olive trees (Olea europaea): E. oleae, and Mallotus japonicus (ornamental tree) E. mallotivora. The genus Pantoea was distantly related and formed a cluster adjacent to the one composed of Erwinia species. The sequences $16 S$ rRNA, atpD, gyrB, infB, and rpoB from CIBCM-Mg-115 have been deposited in the Genbank database (accessions MH643806, MH643807, MH643809, MH643808, and MH643805, respectively).

The API systems and BIOLOG GN microplates failed to identify the bacterial isolate as E. herbicola or Pectobacterium carotovora. Results obtained with GN microplates did not show similarity with any of the Erwinia species in the Biolog database. The CIBCM-Mg-115 isolate from mango is a Gram-negative, oxidase-negative, catalase-positive motile rod that shows the general characteristics of the Enterobacteriaceae and of the species Erwinia billingiae as described by Mergaert et al. (1999), except that nitrate is not reduced to nitrite. As with $E$. billingiae, colonies were white in Nutrient Agar.

Comparative analysis of seven Erwinia species, P. agglomerans, and CIBCM-Mg-115 (Figure 5) using the most relevant biochemical characteristics described for E. billingiae (Mergaert et al., 1999) showed the clustering 


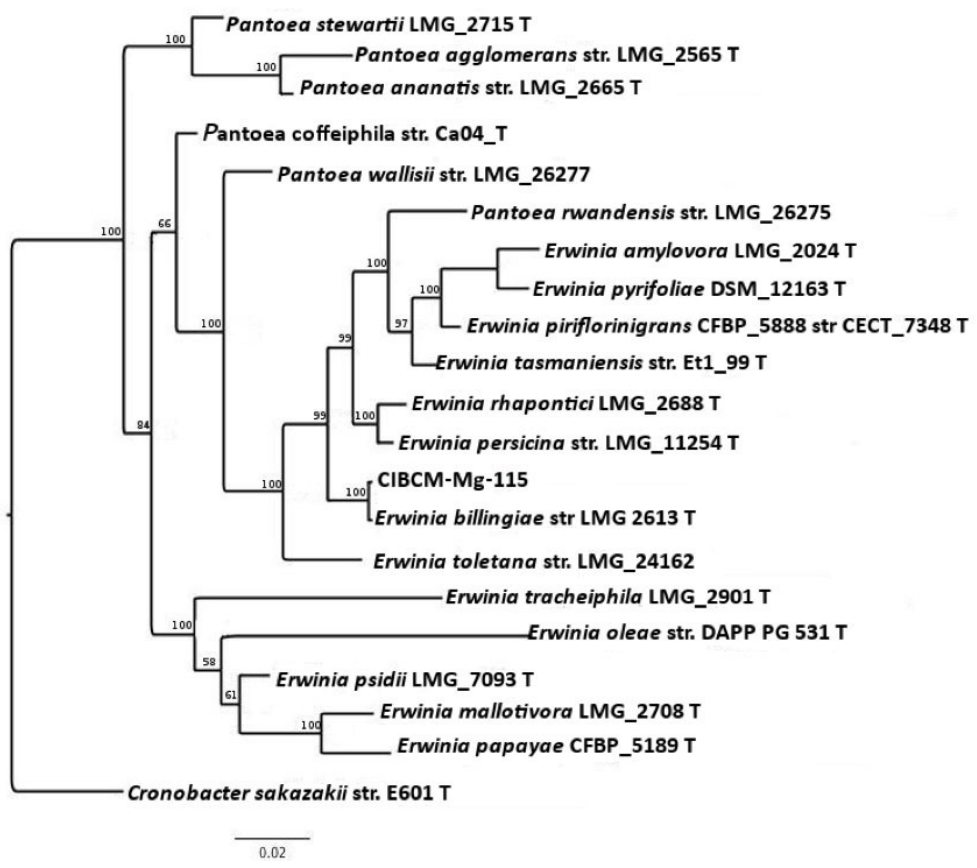

Figure 3. Bayesian tree based on $16 \mathrm{~S}$ rRNA gene sequences showing the position of strain CIBCM-Mg-115 in the genus Erwinia. Bootstrap values are based on 10000000 replications. Cronobacter sakazakii was used as an outgroup. Bar, 0.21 substitutions per nucleotide. San José, Costa Rica. 2018.

Figura 3. Árbol filogenético mediante inferencia bayesiana del gen 16S ARN donde se muestra la posición filogenética de la cepa CIBCM-Mg-115 dentro del género Erwinia. Los valores bootstrap están basados en 10000000 replicaciones. Cronobacter sakazakii se utilizó como grupo externo. Bar, 0.02 sustituciones por nucleótido. San José, Costa Rica. 2018.

of CIBCM-Mg1-115 and E. billingiae with a bootstrap value of $97 \%$, with differences in acid production from D-sorbitol, Myo-inositol, Arbutin, and Salicin. The analysis placed P. agglomerans as an out-group.

\section{Discussion}

The symptom observed in the samples collected in this study corresponds to the same disease mentioned by McMillan \& Wang (1992). In this case, the pathogen attacks trunks, stems, leaves, flowers, and fruits, except the root system that is not susceptible. The infection caused by $X$. campestris is different, especially on the symptoms observed in fruits, where the bacterium causes black spots that can become star shaped latter on (Pruvost et al., 2011), while the lesions caused by Erwinia-like pathogen are irregular, lightly sunken and in the case of branches and stems, a very distinctive red streak on the wood (cambial region) are observed. Severe infection will cause canker in the trunk, with a milky colored sap flowing out. Lesions caused by X. campestris will show a gummy exudate.

Several species from the genus Erwinia have been characterized as pathogens of pome fruit trees. Erwinia amylovora is the causal agent of the fire blight disease of rosaceous plants (Zwet \& Keil, 1979), while E. pyrifoliae, Japanese Erwinia spp., and E. piriflorinigrans cause bacterial diseases of pear (BSBP and BBSDP). However, species as Erwinia billingiae and Erwinia tasmaniensis has been described in other regions as non-pathogenic bacteria (Palacio-Bielsa et al., 2012). 


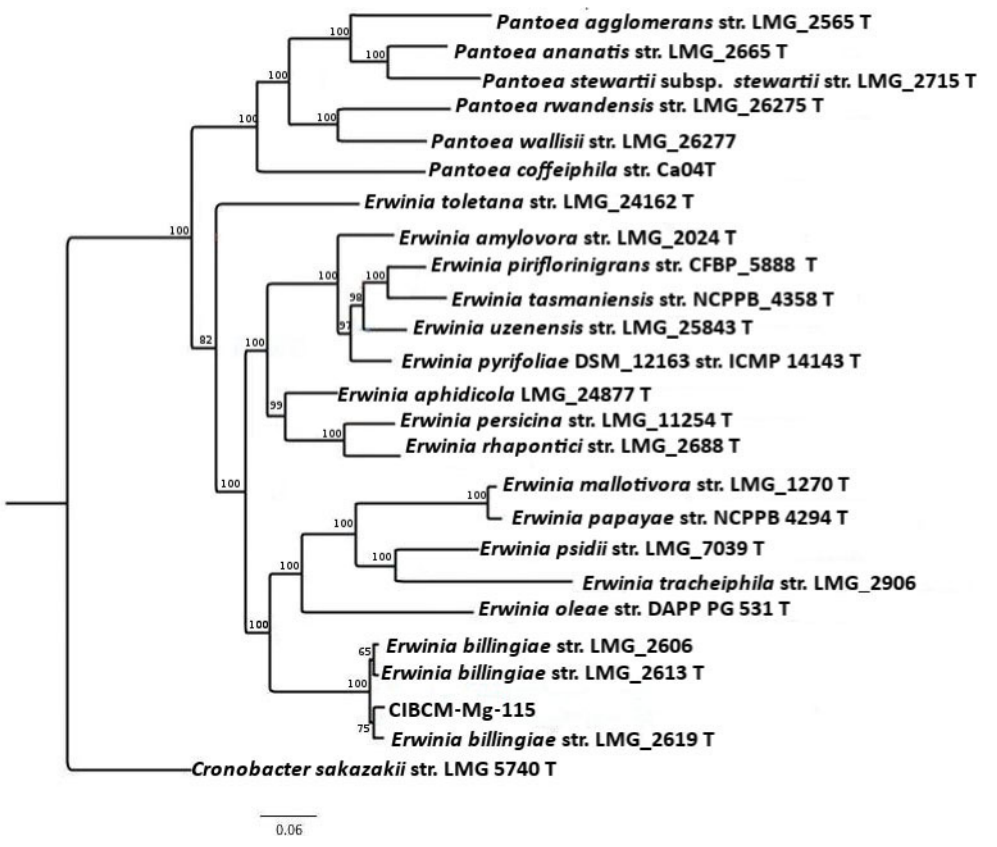

Figure 4. Bayesian analysis of concatenated sequences of the housekeeping genes atpD, gyrB, infB, and rpoB showing the phylogenetic relationship of isolated CIBCM-Mg115 within the genus Erwinia. Bootstrap values are based on 10000000 replications. Cronobacter sakazakki was used as an outgroup. Bar, 0.06 substitutions per nucleotide. San José, Costa Rica. 2018.

Figura 4. Análisis filogenético mediante inferencia bayesiana de las secuencias concatenadas de los genes de mantenimiento atpD, gyrB, infB, y rpoB donde se muestra la posición filogenética de la cepa CIBCM-Mg-115 dentro del género Erwinia. Los valores bootstrap están basados en 10000000 replicaciones. Cronobacter sakazakii se utilizó como grupo externo. Bar, 0,06 sustituciones por nucleótido. San José, Costa Rica. 2018.

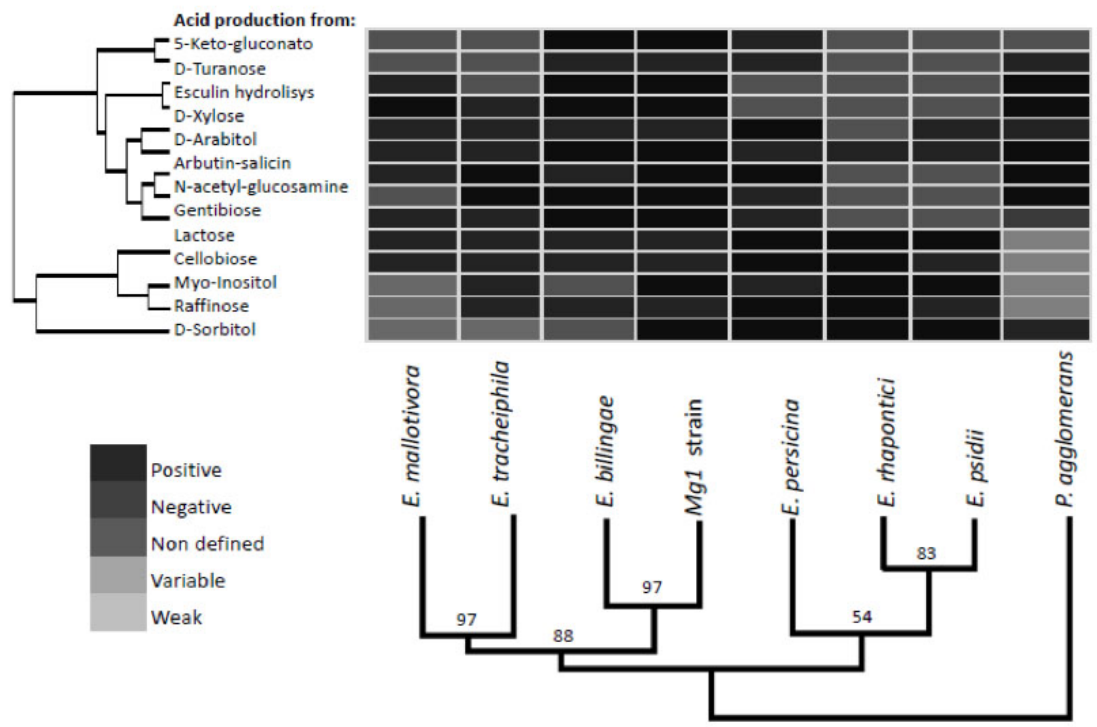

Figure 5. Cluster analysis based on biochemical characteristics to compare similarity between species of Erwinia and Pantoea agglomerans genus. San José, Costa Rica. 2018.

Figura 5. Análisis de agrupamiento basados en características bioquímicas para comparar similitud entre especies del género Erwinia y Pantoea agglomerans. San José, Costa Rica. 2018. 
Strains of Erwinia billingiae were initially designated as E. herbicola (Billing \& Baker, 1963). Bacteria were obtained from different lesions on pear, apple, cherry, hawthorn (Crataegus spp.), and elm (Ulmus spp.) trees and were isolated from symptoms as stem cankers or diseased blossoms and immature fruits.

It was previously classified as white E. herbicola, and was considered to be a secondary invader rather than a primary pathogen. Later, based on DNA-DNA hybridization assays and 16S rDNA sequence analysis, the isolate was reclassified as a novel non-pathogenic species, Erwinia billingiae (Mergaert et al., 1999). E. billingiae tends toinvade necrotic tissue of plants. According to Billing and Baker (1963), English isolates were considered secondary invaders rather than primary pathogens, possibly helping to extend lesions but not to initiate them and it has been demonstrated by other authors (Kube et al., 2010). In this study, it was demonstrate that E. billingiae is a primary pathogen on mango. Artificial inoculation resulted in the development of symptoms identical to what can be seen in the field. According to mango growers, this disease can cause serious losses as it affects the fruit.

Strains of this species have been isolated from apple trees in Poland (Geider et al., 2007) and there are medical reports of dermohypodermitis and bacteremia in a 40-year-old man in Switzerland (Prod'homme et al., 2017) and knee septic arthritis caused by Erwinia billingiae in France, where an immunocompetent patient was treated after a trauma involving a palm tree (Bonnet et al., 2019). The bacterium was identified through 16S rRNA gene sequencing. Bacteria causing initially human pathologies have been described later as plant pathogens. Micrococcus luteus SUBG006 was recognized initially as human pathogen, causing leafspot on M. indica in Rajkot, Gujarat, India (Rakhashiya et al., 2015). The strain was isolated from leaves with black leaf-spot symptoms and characterized by morphological features and sequencing analysis (Rakhashiya et al., 2015). There were no further reports of new isolates of this species as a pathogen or antagonist prior to this study.

\section{Conclusions}

The isolate CIBCM-Mg-115 can be considered as one of the causal agents of bacterial Canker of Mango ( $M$. indica) trees in Costa Rica. This was demonstrated by pathogenicity test, thereby fulfilling Koch's postulates. It was classified as Erwinia billingiae by phylogenetic analysis of the 16S RNA gene and concatenated housekeeping gene sequences, and by cluster analysis of relevant biochemical characteristics described for this species.

\section{References}

Arauz, L. F. (2000). Mango anthracnose: Economic impact and current options for integrated management. Plant Disease, 84(6), 600-611. https://doi.org/10.1094/PDIS.2000.84.6.600

Billing, E., \& Baker, L. A. (1963). Characteristics of Erwinia-like oganisms found in plant material. Journal of Applied Bacteriology, 26(1), 58-65. https://doi.org/10.1111/j.1365-2672.1963.tb01155.x

Bonnet, I., Bozzi, B., Fourniols, E., Mitrovic, S., Soulier-Escrihuela, O., Brossier, F., Sougakoff, W., Robert, J., Jauréguiberry, S., \& Aubry, A. (2019). Erwinia billingiae as unusual cause of septic arthritis, France, 2017. Emerging Infectious Diseases, 25(8), 1587-1589. https://doi.org/10.3201/eid2508.181073

Geider, K., Jock, S., \& Sulikowska. M. (2007). Screening for Erwinia billingiae and E. tasmaniensis in field isolates, differentiation by sequence analysis and effects as antagonists. Acta Horticulturae, 793, 119-121. https://doi. org/10.17660/ActaHortic.2008.793.13

Guevara, M., Rondón, A., \& Solórzano R. (1980). Bacteriosis del mango (Mangifera indica) en Venezuela: Sintomatología e identificación. Agronomía tropical, 30, 65-76. 
Guevara, M., Rondón, A., Arnal, E., \& Solórzano, R. (1985). Bacteriosis del mango (Mangifera indica) en Venezuela II. Distribución, perpetuación, diseminación y evaluación de la resistencia de variedades. Agronomía tropical, 35, 63-75.

Hall, T. A. (1999). BioEdit: a user-friendly biological sequence alignment editor and analysis program for Windows 95/98/NT. Nucleic Acids Symposium Series, 41, 95-98.

Hammer, O., Harper, D. A., \& Ryan, P. D. (2001). PAST-Palaeontological statistics, ver. 1,89. Paleontología Electronica ,4(1), 1-9.

Kishun, R. (1982). Loss in mango fruit due to bacterial canker Xanthomonas mangiferaeindicae. In J. C. Lozano (Ed.), Proceedings of the fifth International Conference on Plant Pathogenic Bacteria (pp. 191-184). Centro Internacional de Agricultura Tropical.

Kube, M., Migdoll, A. M., Gehring, I., Heitmann, K., Mayer, Y., Kuhl, H., Knaust, F., Geider, K., \& Reinhardt, R. (2010). Genome comparison of the epiphytic bacteria Erwinia billingiae and E. tasmaniensis with the pear pathogen E. pyrifoliae. BMC Genomics, 11(1), 393. https://doi.org/10.1186/1471-2164-11-393

Larkin, M. A., Blackshields, G., Brown, N. P., Chenna, R., McGettigan, P. A., McWilliam, H., \& Thompson, J. D. (2007). Clustal W and Clustal X version 2.0. Bioinformatics, 23, 2947-2948. https://doi.org/10.1093/bioinformatics/btm404

López, K. (2011). Oportunidades comerciales para las exportaciones de mango. Promotora de Comercio Exterior. http:// servicios.procomer.go.cr/aplicacion/civ/documentos/Mango.pdf

McMillan, Jr. R. T., \& Wang, A. (1992). A New disease of mango in Costa Rica causes by an Erwinia-like bacteria. Proceedings Florida State Horticultural Society, 105, 288-289

Mergaert, J., Hauben, L., Cnockaert, M. C., \& Swings, J. (1999). Reclassification of non-pigmented Erwinia herbicola strains from trees as Erwinia billingiae sp. Nov. International Journal of Systematic and Evolutionary Microbiology, 49, 377-383. https://doi.org/10.1099/00207713-49-2-377

Mora, J., Gamboa-Porras, J., \& Elizondo-Porras, R. (2002). Guía para el cultivo del mango (Mangifera indica) en Costa Rica. Ministerio de Agricultura y Ganadería.

Palacio-Bielsa, A., Roselló, M., Llop, P., \& López, M. M. (2012). Erwinia spp. from pome fruit trees: similarities and differences among pathogenic and non-pathogenic species. Trees, 26(1), 13-29. https://doi.org/10.1007/s00468-011-0644-9

Prod'homme, M., Micol, L. A., Weitsch, S., Gassend, J.L., Martinet, O., \& Bellini, C. (2017). Cutaneous infection and bactaeremia caused by Erwinia billingiae: a case report. New Microbes and New Infections, 19, 134-136. https://doi. org/10.1016/j.nmni.2017.07.006

Pruvost, O., Boyer, C., Vital, K., Verniere, C., Gagnevin, L., \& Somda, I. (2011). First report in Burkina Faso of Xanthomonas citri pv. mangiferaeindicae causing bacterial canker on Mangifera indica. Plant Disease, 95(10), 1312-1312.

Pruvost, O., Boyer, C., Vital, K., Verniere, C., Gagnevin, L., \& Traoré, Y. N. (2012). First report in Mali of Xanthomonas citri pv. mangiferaeindicae causing mango bacterial canker on Mangifera indica. Plant Disease, 96(4), 581-581. https:// doi.org/10.1094/PDIS-01-12-0001-PDN

Rakhashiya, P. M., Patel, P. P., \& Thaker, V. S. (2015). First Report of Micrococcus luteus Causing Leafspot on Mangifera indica in Rajkot, India. Plant Disease, 99(11), 1640. https://doi.org/10.1094/PDIS-12-14-1359-PDN

Robbs, C. F., \& Rezende, H. B. (1978). Necrose cotiledonar da soja no estado de Minas Gerais. Em Centro Nacional de Pesquisa de Soja (Ed.), Resumos I Seminário Nacional de Pesquisa de Soja (p. 60). Empresa Brasileira de Pesquisa Agropecuária. 
Rondón, G., \& Figueroa, R. (1970). Black spot of mango fruits caused by Erwinia mangifera. Agronomia Tropical, 22(4), 271-274.

Sáenz, A., \& Murillo, A. (1989). Programa nacional sectorial de Mango. Ministerio de Agricultura y Ganadería. http://www. mag.go.cr/bibliotecavirtual/E14-0223.pdf

Schaad, N. W., Jones, J. B., \& Chun, W. (2001). Laboratory guide for the identification of plant pathogenic bacteria. APS Press.

Steyn, P.L., Viljoen, N. M., \& Kotze J. M. (1974). The causal organism of bacterial black spot of mangoes. Phytopathology, $64,1400-1404$.

Tailliez, P., Laroui, C., Ginibre, N., Paule, A., Pagès, S., \& Boemare, N. (2010). Phylogeny of Photorhabdus and Xenorhabdus based on universally conserved protein-coding sequences and implications for the taxonomy of these two genera. Proposal of new taxa: X. vietnamensis sp. nov., P. luminescens subsp. caribbeanensis subsp. nov., P. luminescens subsp. hainanensis subsp. nov., P. temperata subsp. khanii subsp. nov., P. temperata subsp. tasmaniensis subsp. nov., and the reclassification of $P$. luminescens subsp. thracensis as P. temperata subsp. thracensis comb. Nov. International Journal of Systematic and Evolutionary Microbiology, 60, 1921-1937. https://doi.org/10.1099/ijs.0.014308-0

Tamura, K., Stecher, G., Peterson, D., Filipski, A., \& Kumar, S. (2013). MEGA6: molecular evolutionary genetics analysis version 6.0. Molecular Biology and Evolution, 30(12), 2725-2729. https://doi.org/10.1093/molbev/mst197

Ureña, A. L., González, J., Meneses, R., \& Alvarado E. (2007). Agrocadena de mango. Ministerio de Agricultura y Ganadería. http://www.mag.go.cr/bibliotecavirtual/E70-4282.pdf

Viljoen, N. M., \& Kotzë, J. M. (1972). Bacterial black spot of Mango. The Citrus Grower and Sub-tropical Fruit Journal, 462, $5-8$.

Yanxiang, Q., He, Z., Jinji, P., Xin, Z., Quanfang, Y., Ying, L., \& Yixian, X. (2016). Characterization of Chinese Isolates of Mango Bacterial Canker Xanthomonas campestris pv. mangiferaeindicae. Plant Diseases and Pests, 7(3), 33.

Young, A. (2008). Notes on Pseudomonas syringae pv. syringae bacterial necrosis of mango (Mangifera indica) in Australia. Australasian Plant Disease Notes, 3(1), 138-140. https://doi.org/10.1007/BF03211269.

Zwet, T. V. D., \& Keil, H. L. (1979). Fire blight: a bacterial disease of Rosaceous plants. United States Department of Agriculture. 